\title{
Sistem Bagi Hasil Penggarapan Sawah di Desa Bedegung Kecamatan Semidang Aji (Studi Kasus Desa Bedegung Kecamatan Semidang Aji Kabupaten OKU)
}

\author{
Anita Mauliyanti \\ Sekolah Tinggi Agama Islam Baturaja \\ Email: Amauliyanti@yahoo.com
}

Abstract : The aim of this research is to study the profit sharing in the rice cultivation system and study the perspective of Islamic law on the results in the rice cultivation system in Bedegung Village, Semidang Aji District, Ogan Komering Ulu Regency. This research is a qualitative research. The data sources used in this study are two, namely primary data and secondary data. The research location was in Bedegung Village, Semidang Aji District, Ogan Komering Ulu Regency for 60 days. Data collection techniques used in this study were interviews, observation, and documentation. Profit sharing in the system of cultivating paddy fields in Bedegung Village, Semidang Aji District, Ogan Komering Ulu Regency is known as Paruan where the land owner connects the land to the cultivator to be cultivated with the help of flowers) while the cultivators get one (1) part. If the fund is cultivated, then the portion gets 2 parts while the land owner gets 1 part. Likewise, the costs are borne jointly, then the portion obtained between the land owner and each tiller (1/2). From the perspective of Islamic law the Profit Sharing System in Cultivation of Rice Fields is not appropriate because it contains ghororic elements. The lack of clarity requested was the muzara'ah contract and mukhabarah regarding the contract agreement, because the landowners and tenants were not present in the agreement and the results of the agreement were not only written verbally. However, it is incomplete with Islamic law because the practice carried out by the Bedegung Village community is carried out on the basis of liking and liking unpleasant to help,

Keywords : profit sharing, rice cultivation, and Islamic law

Abstrak : Penelitian ini bertujuan untuk mengetahui bagi hasil dalam sistem pengarapan sawah dan mengetahui perspektif hukum Islam terhadap bagi hasil dalam sistem penggarapan sawah di Desa Bedegung Kecamatan Semidang Aji, Kabupaten Ogan Komering Ulu. Penelitian ini termasuk jenis penelitian kualitatif. Sumber data yang digunakan dalam penelitian ini ada dua, yaitu data primer dan data sekunder. Lokasi penelitian ada di Desa Bedegung Kecamatan Semidang Aji, Kabupaten Ogan Komering Ulu selama 60 hari. Teknik pengumpulan data yang digunakan dalam penelitian ini yaitu wawancara, observasi, dan dokumentasi. Bagi hasil dalam sistem penggarapan sawah di Desa Bedegung Kecamatan Semidang Aji, Kabupaten Ogan Komering Ulu dikenal dengan istilah Paruan dimana seorang pemilik tanah menyerahkan lahan tersebut kepada penggarap untuk diolahnya dengan ketentuan apabila semua biaya ditanggung oleh pemilik tanah, maka bagian pemilik tanah mendapat dua (2) bagian sementara penggarap mendapat satu (1) bagian. Jika penggarap menanggung biaya maka bagiannya mendapat 2 bagian sementara pemilik tanah mendapat 1 bagian. Demikian juga apabila biaya ditanggung bersama maka bagian yang didapat antara pemilik tanah dan penggarap masing-masing $(1 / 2)$. Dari perspektif hukum Islam Sistem Bagi Hasil dalam Penggarapan Sawah belum sesuai karena mengandung unsur 
ghoror. Ketidakjelasan yang dimaksud adalah akad muzara'ah dan mukhabarah mengenai perjanjian akad, karena pemilik tanah dan penggarap tidak menghadirkan saksi dalam perjanjian serta hasil perjanjian tidak ditulis hanya secara lisan. Namum tidak sepenuhnya bertentangan dengan hukum islam karena praktek yang dilakukan oleh masyarakat Desa Bedegung ini dilakukan atas dasar suka sama suka dan mengandung unsur tolong menolong.

Kata kunci : Bagi hasil, penggarapan sawah, dan hukum Islam

\section{A. Pendahuluan}

Indonesia adalah negara agraris yang sebagian besar wilayahnya adalah daerah pedesaan dan masyarakatnya mempunyai mata pencaharian sebagai petani. Lahan pertanian di pedesaan masih sangat luas, namun tidak semua masyarakat desa yang bermatapencaharian sebagai petani tersebut mempunyai lahan pertanian, sehingga sebagian besar petani yang tidak mempunyai lahan pertanian sendiri bekerja sebagai buruh tani. Nilai gotong royong dapat dimanfaatkan secara positif dalam kehidupan untuk menggerakkan solidaritas sosial agar bangsa Indonesia mampu menghadapi tantangan perubahan zaman, globalisasi, maupun berbagai hal yang mengancam kehidupan masyarakat seperti bencana alam, konflik sosial maupun politik. Gotong royong menjadi pranata untuk menggerakkan solidaritas masyarakat dan menciptakan kohesi sosial dalam kehidupan bangsa Indonesia. ${ }^{1}$

Sektor pertanian sangat berperan dalam penyerapan tenaga kerja di pedesaan, terutama bagi masyarakat yang berpendidikan rendah. Sehingga sebagian besar masyarakat pedesaan bekerja di sektor pertanian. Pertanian merupakan salah satu bentuk usaha yang dilakukan oleh masyarakat, terutama masyarakat pedesaan dengan memanfatkan sumber daya modal dan sumber daya alam yang ada seperti: tanah dan air. $^{2}$

Kegiatan pemanfaatan sumber daya hayati yang termasuk dalam pertanian biasa dipahami orang sebagai budidaya tanaman atau bercocok tanam. Sebagian besar penduduk indonesia hidup dari hasil bercocok tanam atau petani. Pertanian merupakan sektor yang memegang peranan penting dalam kesejahteraan penduduk indonesia. Di antara anggota masyarakat, ada yang memiliki lahan pertanian (sawah atau ladang), tetapi tidak mampu mengerjakannya (mengolahnya), mungkin karena sibuk dengan kegiatan lain atau memang tidak punya keahlian (skill, keterampilan) untuk bertani. Sebaliknya, ada juga di antara anggota masyarakat yang tidak mempunyai lahan pertanian tetapi ada kemampuan untuk mengolahnya.

Setelah melihat kenyataan ini dalam masyarakat, maka pemilik lahan pertanian menyerahkan lahannya kepada penggarap untuk ditanami hingga kedua belah pihak saling menguntungkan. Dengan demikian, rasa tolong-menolong, saling memperdulikan akan tumbuh dan berkembang dalam masyarakat, sesuai dengan firman Allah Qs. AlMaidah ayat 2:

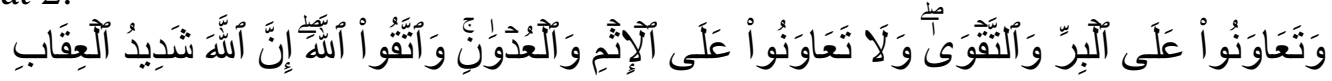

1 Tri Wahyuningsih, "Sistem Bagi Hasil Maro Sebagai Upaya Mewujudkan Solidaritas Masyarakat," Komunitas: International Journal of Indonesian Society and Culture 3, no. 2 (2013): 197-204.

${ }^{2}$ Mochammad Kamil Malik, Sri Wahyuni, and Joko Widodo, "Sistem Bagi Hasil Petani Penyakap Di Desa Krai Kecamatan Yosowilangun Kabupaten Lumajang,” JURNAL PENDIDIKAN EKONOMI: Jurnal Ilmiah Ilmu Pendidikan, Ilmu Ekonomi dan Ilmu Sosial 12, no. 1 (2018): 26. 
Artinya : "dan tolong-menolonglah kamu dalam (mengerjakan) kebajikan dan takwa, dan jangan tolong-menolong dalam berbuat dosa dan pelanggaran. dan bertakwalah kamu kepada Allah, Sesungguhnya Allah Amat berat siksa-Nya”.

Melalui ayat ini, Allah SWT memerintah umat-Nya untuk saling membantu satu sama lain, serta tolong-menolong dalam mengerjakan kebajikan-kebajikan dan ketaqwaan. Sebaliknya, Allah melarang kita untuk saling menolong dalam melakukan perbuatan dosa dan pelanggaran. Salah satu bentuk nyata dari tolong-menolong adalah dengan melakukan transaksi, sebab dalam pemenuhan kebutuhan hidupnya manusia tidak dapat melakukannya sendiri, melainkan membutuhkan pertolongan orang lain. Dalam transaksi yang dilakukan sesama manusia dibutuhkan sebuah kesepakatan, dan kesepakatan tersebut salah satunya diwujudkan dalam bentuk perikatan.

Dalam hukum Islam, kerjasama dalam pertanian biasanya disebut dengan tiga istilah yakni musaqah, muzara'ah, dan mukhabarah. Akad musaqah adalah sebuah bentuk kerja sama antara pemilik kebun dan petani penggarap dengan tujuan agar kebun itu dipelihara, dan dirawat sehingga memberikan hasil yang maksimal, kemudian hasil tersebut sebagian menjadi bagian (upah) bagi penggarap yang mengurusnya sesuai dengan kesepatakan yang mereka buat. ${ }^{3}$ Kerjasama dalam bentuk musaqah berbeda dengan mengupah tukang kebun untuk merawat tanaman, karena hasil yang diterimanya adalah bukan upah yang telah pasti ukurannya seperti tukang kebun, melainkan dari hasil kebun yang belum tentu besarannya. ${ }^{4}$ Begitu juga dalam pertanian, bentuk sistem pertanian yang dipakai oleh masyarakat bermacam-macam sesuai dengan kondisi dan adat istiadat setempat sesuai dengan syari'at islam. Sama halnya dengan sistem pertanian di Desa Bedegung kebanyakan mata pencarian masyarakatnya adalah bertani. Bentuk pengolahan lahan pertanian yang digunakan yakni sistem bagi hasil. Sistem tersebut adalah suatu jenis kerja sama antara penggarap dengan pemilik lahan, di mana pemilik lahan menyerahkan lahan pertanian untuk digarap oleh pihak penggarap. Dalam hal ini, penggarap menerima lahan tersebut untuk digarap dengan konsekuensi hasil yang dicapai.

Praktek bagi hasil, pemilik lahan dan penggarap sawah melakukan perjanjian terlebih dahulu. Dalam perjanjian tersebut ditentukan kapan penggarap dapat memulai melakukan penggarapan lahan dan dalam perjanjian tersebut juga ditentukan kapan waktu berakhir penggarapan yaitu setelah selesai panen. Namun jika tidak ada masalah antara pemilik lahan dengan pengelola lahan maka perjanjian akan di lanjutkan kembali. Dalam perjanjian, tanaman yang biasa ditanam yaitu padi. Bagi hasil panen tersebut dilakukan sesuai dengan kebiasaan dan adat di Desa Bedegung yakni apabila semua biaya ditanggung oleh pemilik tanah, maka bagian pemilik sawah mendapat dua (2) bagian sementara penggarap mendapat satu (1) bagian. Jika penggarap menanggung biaya maka bagiannya mendapat 2 bagian sementara pemilik tanah mendapat 1 bagian. Demikian juga apabila biaya ditanggung bersama maka bagian yang didapat antara pemilik tanah dan penggarap masing-masing $(1 / 2) .^{5}$

Dalam masa pengolahan atau penggarapan lahan pertanian, pihak pemilik lahan hanya menyerahkan lahan dan pihak penggarap berkewajiban dalam mengurusi masalah

\footnotetext{
${ }^{3}$ Abdul Rahman Ghazaly dan Sapiudin Shidiq, Fiqh Muamalat (Jakarta: Kencana, 2015). h. 46

${ }^{4}$ Unggul Priyadi dan and Jannahar Saddam Ash Shidiqie, "Pelaksanaan Perjanjian Bagi Hasil Pertanian Lahan Sawah Studi Di Studi Di Kecamatan Gamping, Kabupaten Sleman Yogyakarta,” Millah XV No 1 (2015): 101-115, www.regionalinvestment.bkpm.go.id.

${ }^{5}$ Wawancara dengan M. Yanoh, Kepala Desa Bedegung, Bedegung, 02 Mei 2019
} 
pengolahan lahan, pengairan, pemeliharaan tanaman dan biaya operasionalnya. Untuk bibit dan pupuk diusahakan oleh pihak penggarap selama masa penggarapan lahan berlangsung. Pada saat panen, biaya bibit dan pupuk akan dihitung untuk ditanggung bersama. Perjanjian bagi hasil yang dilakukan kedua belah pihak yakni secara lisan saja dan tanpa adanya saksi namun ada juga yang menghadirkan saksi.

\section{B. Metode Penelitian}

Penelitian dilaksanakan dengan menggunakan pendekatan kualitatif, dengan desain deskriptif kualitatif dengan format studi kasus. Alasan penggunaan metode penelitian kualitatif karena pertimbangan jenis data yang akan dikumpulkan, dan dianalisis membutuhkan metode ini. Data yang yang akan dikumpulkan berupa kata-kata, dan perbuatan manusia. Data dalam penelitian ini adalah sistem bagi hasil penggarapan sawah di Desa Bedegung Kecamatan Semidang Aji. Data tersebut tidak diupayakan untuk dikuantifikasikan (dihitung), melainkan diintrepretasikan dan ditangkap apa yang terungkap dari data yang telah dikumpulkan yaitu sistem bagi hasil penggarapan sawah di Desa Bedegung Kecamatan Semidang Aji. ${ }^{6}$

Penelitian ini dilakukan di Desa Bedegung Kecamatan Semidang Aji Kabupaten Ogan Komering Ulu Provinsi Sumatera Selatan. Jenis data yang digunakan pada penelitian ini dapat diklasifikasikan menjadi dua jenis yaitu data primer dan sekunder. Data primer diperoleh dari objek penelitian atau diperoleh langsung dari lapangan buku panduan atau pedoman Desa, wawancara dengan para informan. informan dalam penelitian ini adalah pemilik sawah, pengelola sawah, tokoh agama dan masyarakat setempat. Data ini dapat diperoleh melalui wawancara langsung antara peneliti dengan subjek penelitian dan dapat diperoleh pula melalui observasi. ${ }^{7}$ Data sekunder diperoleh dari buku-buku, artikel, jurnal, internet, dan media-media lain yang relevan dengan topik penelitian ini.

Kriteria sumber data dalam penelitian ini menggunakan snowball sampling dalam menentukan dan menemukan informan. Kriteria informan adalah pemilik dan penggarap sawah yang melakukan perjanjian sistem bagi hasil di Desa Bedegung Kecamatan Semidang Aji. Kriteria informan pendukung adalah, tojoh masyarakat, pejabat pemerintah desa Bedegung di Kecamatan Semidang Aji, dan pejabat pemerintah Kecamatan Semidang Aji.

\section{Hasil Penelitian dan Pembahasan}

\section{Musaqah}

Musaqah dalam arti bahasa merupakan wazn mufa'alah dari kata assaqyu yang sinonimnya asy-syurbu, artinya memberi minum. Penduduk madinah menamai musaqah dengan mu'amalah, yang merupakan wazn mufa'alah dari kata 'amila yang artinya bekerja (bekerja sama). Menurut syara' musaqah adalah suatu akad penyerahan pepohonan kepada orang yang mau menggarapnya dengan ketentuan hasil buah-buahan dibagi di antara mereka berdua.

Menurut ulama Syafi'iyah, mendefinisikan al-musaqah adalah melakukan muamalah dengan orang lain atas pohon kurma atau pepohonan

\footnotetext{
${ }^{6}$ Sudrajat M. Subana, Dasar-Dasar Penelitian Ilmiah (Jakarta: CV Pustaka Setia, 2011). h. 25

${ }^{7}$ Rosady Ruslan, Metode Penelitian: Public Relations \& Komunikasi (Jakarta: Raja Grafindo Persada, 2008). h. 29
} 
atau anggur saja, untuk diurus dengan menyiraminya dan merawatnya dengan ketentuan hasil buahnya dibagi di antara mereka berdua. ${ }^{8}$

Menurut Muhammad Syafieci Antonio dalam Bukunya Bank Syariah dari Teori ke Praktek, mengartikan al-musaqah adalah bentuk yang lebih sederhana dari muzara'ah di mana si penggarap hanya bertanggung jawab atas penyiraman dan pemeliharaan. Sebagai imbalan, si penggarap berhak atas nisbah tertentu dari hasil panen. ${ }^{9}$

Dasar hukum musaqah ialah dalam sebuah hadis yang menerangkan tentang diperbolehkannya untuk pelaksanaan kerja sama dalam bentuk musaqah untuk penggarap dan pemilik lahan pertanian.

Menurut Abu dan Muhammad bin Hasan serta jumhur ulama (Malik, Syafi'i, dan Ahmad), musaqah dibolehkan dengan beberapa syarat. Pendapat ini didasarkan kepada hadis Nabi Shallallahu Alaihi Wa Sallam : "Dari Ibnu 'Umar bahwa Nabi Shallallahu Alaihi Wa Sallam bekerja sama dengan penduduk Khaibar (menyirami tanaman) dengan imbalan separuh dari hasil yang diperoleh, baik berupa buah-buahan maupun pepohonan". ${ }^{10}$ (HR. Jama'ah)/

Dalam hadis yang diriwayatkan oleh Imam Muslim dari Ibnu Umar Radhiallahu Anhu juga menjelaskan bahwa Musaqah diperbolehkan: "Dari Ibnu Umar r.a. sesungguhnya Rasulullah Shallallahu Alaihi Wa Sallam. Telah memberikan kebun beliau kepada penduduk Khaibar agar dipelihara oleh mereka dengan perjanjian mereka akan memperoleh setengah dari penghasilannya, baik dari buah-buahan maupun tanamannya." (HR. Muslim). ${ }^{11}$

Menurut Abu Ja'far Muhammad bin Ali Husain bin Abu Thalib r,a, bahwa Rasulullah SAW telah menjadikan penduduk Khaibar sebagai penggarap dan memelihara atas dasar bagi hasil. Hal ini dilanjutkan oleh Abu Bakar, Umar, Ali Serta keluarga-keluarga mereka sampai hari ini dengan rasio 1/3 dan 1/4. Semua telah dilakukan oleh Khulafaur rasyidin pada zaman pemerintahannya dan semua pihak yang telah mengetahuinya, akan tetapi tidak ada seorang pun yang menyanggahnya, berarti ini adalah ijma' sukuti (konsensus dari umat). ${ }^{12}$

Menurut Hanafiah, rukun musaqah adalah ijab dan qobul. Ijab dinyatakan oleh pemilik pepohonan, sedangkan qobul dinyatakan oleh penggarap ('amil atau muzari'). Menurut Malikiyah, akad musaqah mengikat (lazim) dengan diucapkannya lafal ijab qobul, tidak dengan pekerjaan. Sedangkan menurut Hanabilah, musaqah sama dengan muzara'ah, tidak perlu ijab qobul dengan lafal, melainkan cukup dengan memulai penggarapan secara langsung. Syafi'iyah justru mensyaratkan adanya qobul dengan lafal. Menurut jumhur ulama rukun musaqah ada tiga,

\footnotetext{
${ }^{8}$ Ahmad Wardi Muslich, Fiqh Muamalah (Jakarta: Sinar Grafika, 2006). h. 404-405

${ }^{9}$ Muhammad Syafi'i Antonio, Bank Syariah Dari Teori Ke Praktek (Jakarta: Gema Insani, 2001). h. 100

${ }^{10}$ Muslich, Fiqh Muamalah. h. 406

${ }^{11}$ Ibnu Hajar Al-Asqalani, Bulughul Marom, diterjemah. (Jakarta: Pustaka Amani, 2000). h. 438

${ }^{12}$ Mardani, Fiqh Ekonomi Syariah, 1st ed. (Jakarta: Kencana, 2012). h. 242
} 
yaitu 'Aqidain (pemilik kebun dan penggarap), objek akad, yaitu pekerjaan dan buah dan sigha (ijab dan qabul). ${ }^{13}$

Sedangkan syarat-syarat musaqah pada dasarnya tidak jauh berbeda dengan syarat-syarat muzara'ah. Hanya saja dalam musaqah tidak disyaratkan untuk menjelaskan jenis bibit, pemilik bibit, kelayakan tanah untuk ditanami, dan ketentuan waktunya.

\section{Muzara'ah}

Secara etimologi, muzara'ah berarti kerja sama di bidang pertanian anatar apihak pemilik tanah dan petani penggarap. Secara terminologi, terdapat beberapa definisi muzara'ah yang dikemukakan ulama fiqh. Ulama Malikiyah menefinisikan muzara'ah adalah perserikatan dalam pertanian. ${ }^{14}$ Ulama Hanabilah mendefinisikan muzara'ah adalah penyerahan tanah pertanian kepada seorang petani untuk digarap dan hasilnya dibagi berdua. ${ }^{15}$

Kedua definisi ini dalam kebiasaan Indonesia disebut sebagai "paruhan sawah". Penduduk irak menyebutnya al-mukhabarah, tetapi dalam al-mukhabarah, bibit yang akan ditanam berasal dari pemilik tanah. Imam Syafi'i mendefinisikan muzara'ah adalah transaksi antara penggarap (dengan pemilik tanah) untuk menggarap tanah dengan imbalan sebagian dari hasil yang keluar dari tanah tersebut dengan ketentuan bibit dari pemilik tanah. ${ }^{16}$

Kerja sama dalam bentuk muzara'ah menurut kebanyakan ulama fiqh hukumnya mubah (boleh). Dasar kebolehan itu, adalah firman Allah tentang tolong menolong.

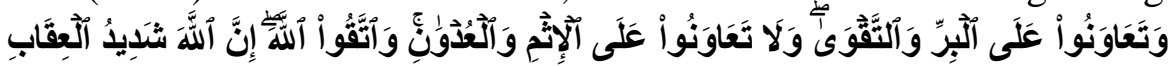

Artinya : dan tolong-menolonglah kamu dalam (mengerjakan) kebajikan dan takwa, dan jangan tolong-menolong dalam berbuat dosa dan pelanggaran. dan bertakwalah kamu kepada Allah, Sesungguhnya Allah Amat berat siksa-Nya.(QS. Al-Maidah ayat 2).

Dasar hukum lain yang digunakan para ulama' dalam menetapkan hukum muzara'ah adalah sebuah hadits yang diriwayatkan oleh Bukhari dan Muslim dari Ibnu Abbas ra. ${ }^{17}$

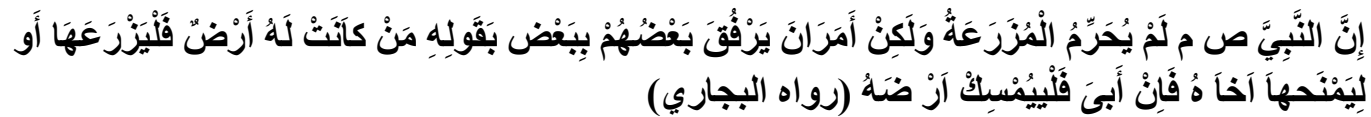

“Sesungguhnya Nabi saw. Menyatakan, tidak mengharamkan bermuzarara'ah bahkan beliau menyuruhnya, supaya yang sebagian menyayangi sebagian yang lain, dengan katanya, barang siapa yang memiliki tanah, maka hendaklah ditanaminya atau memberikan faedahnya kepada saudaranya, jika ia tidak mau, maka boleh ditahan saja tanah itu”. (HR. Bukhari dan Muslim)

Jumhur ulama yang membolehkan akad muzara'ah mengemukakan rukun dan syarat yang harus dipenuhi, sehingga akad dianggap sah. Rukun muzara'ah menurut mereka adalah Pemilik tanah, Petani penggarap, objek al-muzara'ah dan Ijab dan

\footnotetext{
${ }^{13}$ Ibid. h. 407

${ }^{14}$ Abdul Rahman Ghazaly, dkk, Fiqh Muamalat (Jakarta: Penerbit Kencana, 2010), hlm. 114

${ }^{15}$ Ibid., hlm., 114

${ }^{16}$ Muslich, Fiqh Muamalah. h. 393

${ }^{17}$ Ruf'ah Abdulla Sohari Sahrani, Fikih Muamalah (Bogor: Ghalia Indonesia, 2011).h. 215
} 
Qobul. ${ }^{18}$ Adapun syarat-syarat muzara'ah, menurut jumhur ulama adalah syarat yang menyangkut orang yang berakad, keduanya harus sudah balig dan berakal, syarat yang menyangkut benih yang akan ditanam harus jelas, sehingga benih yang akan ditanam itu jelas dan akan menghasilkan, syarat yang menyangkut tanah pertanian yaitu menurut adat di kalangan para petani, tanah itu boleh digarap dan menghasilkan. Jika tanah itu tanah tandus dan kering sehingga tidak memungkinkan untuk dijadikan tanah pertanian, maka akad muzara'ah tidak sah, batas-batas tanah itu jelas, tanah itu sepenuhnya diserahkan ke petani penggarap untuk digarap. Apabila disyaratkan bahwa pemilik tanah ikut mengelola pertanian itu maka akad muzara'ah tidak sah.

Syarat selanjutnya yaitu syarat-syarat yang menyangkut dengan hasil panen adalah pembagian hasil panen bagi masing-masing pihak harus jelas, hasil itu benarbenar milik bersama orang yang berakad, tanpa boleh ada pengkhususan. ${ }^{19}$ Pembagian hasil panen itu ditentukan: setengah, sepertiga atau seperempat, sejak dari awal akad, sehingga tidak timbul perselisihan di kemudian hari dan penentuannya tidak boleh berdasarkan jumlah tertentu secara mutlak, seperti satu kwintal untuk pekerja atau satu karung karena kemungkinan seluruh hasil panen jauh di bawah itu atau dapat juga jauh melampaui jumlah itu. Syarat terakhir yaitu syarat yang menyangkut jangka waktu juga harus dijelaskan dalam akad sejak semula, karena akad muzara'ah mengandung makna akad al-ijarah (sewa-menyewa atau upah mengupa) dengan imbalan sebagian hasil panen. Oleh sebab itu, jangka waktunya harus jelas. Untuk penentuan jangka waktu ini biasanya disesuaikan dengan adat setempat. $^{20}$

\section{Mukhabarah}

Mukhabarah adalah bentuk kerjasama antara pemilik sawah / tanah dan penggarap dengan perjanjian bahwahasilnya akan dibagi antara pemilik tanah dan penggarap menurut kesepakatan bersama, sedangkan biaya, dan benihnya dari penggarap tanah. $^{21}$

Bentuk kerja sama antara pemilik tanah dan penggarap dengan perjanjian bahwa hasilnya akan dibagi menurut kesepakatan bersama, sedangkan biaya, dan benihnya dari penggarap tanah. Menurut Syaikh Ibrahim Al-bajuri berpendapat bahwa mukhabarah adalah, sesungguhnya pemilik hanya menyerahkan tanah kepada pekerja

\footnotetext{
${ }^{18}$ Abdul Rahman, dkk, Op.cit., hlm. 115

${ }^{19}$ Ibid., hlm., 116

${ }^{20}$ Ibid., hlm., 117

${ }^{21}$ Abdul Rahman, dkk, Op.cit., hlm. 114
} 
dan modal dari pengelola. ${ }^{22}$ Ulama' Syafi'iyah membedakan antara muzara'ah dan mukhabarah:

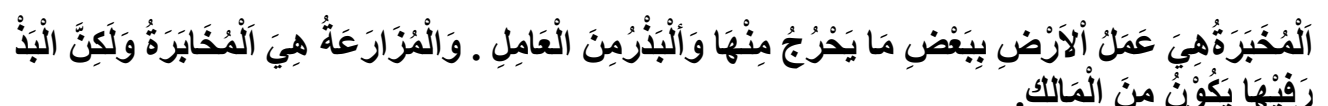

"Mukhabarah adalah mengelola tanah diatas sesuatu yang dihasilkannya dan benihnya berasal dari pengelola. Adapun muzara'ah sama seperti Mukabarah, hanya saja benihnya berasal dari pemilik tanah ${ }^{23 " .}$

Pengertian antara al-muzara'ah dan al-mukhabarah terdapat pengertian yang sama dan pengertian yang berbeda. Persamaanya terletak pemilik tanah menyerahkan tanahnya kepada pihak lain untuk dikelola. Sedangkan perbedaannya pada modal, jika modal berasal dari pemilik tanah disebut muzara'ah, dan jika modal berasal dari pengelola disebut al-mukhabarah. Dan pada umumnya, kerja sama mukhabarah ini dilakukan pada perkebunan yang benihnya relatif murah, seperti padi, jagung, dan kacang. Namun tidak tertutup kemungkinan pada tanaman yang benihnya relatif murah pun dilakukan kerjasama muzara'ah.

Dasar hukum mukhabarah sama dengan muzara'ah, yaitu mubah (boleh). Landasan mukhabarah adalah sabda Nabi

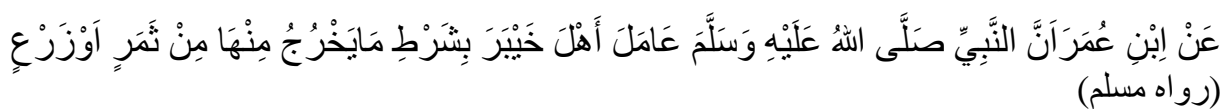

Dari Ibnu Umar: "Sesungguhna Nabi SAW. Telah memberikan kebun kepada penduduk khaibar agar dipelihara oleh mereka dengan perjanjian mereka akan diberi sebagian dari penghasilan, baik dari buah - buahan maupun dari hasil pertahun (palawija)." (H.R Muslim)

\section{Hak dan Kewajiban Pemilik Sawah}

Pemilik tanah dalam perjanjian bagi hasil berhak memperoleh bagian dari hasil sawahnya pada saat dilakukan panen sesuai dengan perjanjian yang telah disepakati kedua belah pihak. Sebagian dalam hal ini berarti sepertiga bagian di mana satu bagian bagi pemilik sawah dan dua bagian untuk penggarap dengan ketentuan yang menyediakan seluruhnya termasuk bibit, pupuk, dan obat-obatan ditanggung penggarap. Dan jika pemilik sawah menyediakan seluruhnya termasuk bibit, pupuk, dan obat-obatan maka pemilik sawah mendapatkan dua bagian dan petani penggarap mendapatkan satu bagian. ${ }^{24}$

Di samping itu pemilik tanah pula berhak untuk mengambil tanahnya kembali jika terjadi maslah dengan penggarap atau ada salah satu pihak yang merasa dirugikan. Namun jika tidak ada masalah maka pemilik tanah juga berhak untuk tetap melanjutkan perjanjian dengan petani penggarap sawah. Selain dari hak pemilik di atas, maka pemilik tanah juga mempunyai beban kewajibannya yang harus dilaksanakan, yaitu kewajiban untuk membayar pajak tanah yang bersangkutan. Kewajiban itu tegas dinyatakandalam pasal 9 Undang-Undang No. 2 Tahun 1960 tentang Perjanjian Bagi Hasil Pertanian, di mana pasal ini memberikan kewajiban

\footnotetext{
${ }^{22}$ Hendi Suhendi, Fiqih Muamalah (Jakarta: PT. Raja Grofindo Persada, 2013). h. 54

${ }^{23}$ Rachmat Syafe'I, Fiqh Muamalah (Bandung: Pustaka Setia, 2000). h. 206

${ }^{24}$ Wawancara dengan Rusadin, Tokoh Masyarakat Desa Bedegung, Bedegung, 20 Oktober 2019
} 
kepada pemilik tanah untuk membayar tanah yang bersangkutan dan melarangnya apabila penggarap adalah pemiliknya sendiri. Jadi secara formal kewajiban membayar pajak ada pada pemilik tanah, hal ini di sebabkan denganketentuan yang berlaku sekarang. ${ }^{25}$

\section{Hak dan Kewajiban Penggarap Sawah}

Perjanjian bagi hasil yang dilakukan oleh pemilik tanah dan penggarapnya selain meletakkan hak dan kewajiban pemilik tanah juga meletakkan hak dan kewajiban penggarap. Adapun yang menjadikan dari penggarap dalam hal perjanjian bagi hasil tersebut dalam memperoleh sebagian dari tanah garapnya sebagian imbalan jasanya sesuai isi perjanjian yang telah disepakati bersama. Selain hak dari penggarap sebagaimana yang diuraikan di atas, maka terdapat pula kewajiban yang harus dipenuhi oleh penggarap, kewajiban tersebut yaitu memelihara atau mengerjakan tanah persawahan tesebut secara baik dan teratur sebagaimana seorang pemilik sendiri. Bila penggarap sudah tidak mampu mengerjakannya tanah tersebut secara baik dan teratur, maka penggarap berkewajiban mengembalikannya kepada pemilik tanah sesuai ditegaskan dalam pasal 10 Undang-Undang No. 2 Tahun 1960 tentang Perjanjian Bagi Hasil Pertanian, dan petani penggarap akan mengembalikan tanah tersebut kepada pemilik tanah secara baik seperti ia mandapatkan sebelumnya. Penggarap bekewajiban mengembalikan tanah tersebut dalam keadaan baik. Pengertian dalam keadaan baik tidak dapat dijelaskan secara tegas, tetapi dapat dikatakan bahwa penggarap mengembalikan tanah pemilik dalam keadaan tidak merugikan pemilik tanah, tergantung dari keadaan dan ukuran setempat.

Hak dan kewajiban adalah dua sisi yang saling memiliki timbal balik dalam suatu transaksi. Hak adalah suatu pihak yang merupakan kewajiban bagi pihak menjadi pihak lain, begitu pula sebaliknya kewajiban salah satu pihak manjadi hak bagi pihak yang lain. Keduanya saling berhadapan dan diakui dalam metode hukum Islam. Dalam hukum Islam, hak adalah kepentingan yang ada pada perorangan atau masyarakat, dengan hak seseorang terhadap kewajiban orang lain untuk saling menghormati. ${ }^{26}$ Namun demikian, secara umum pengertian hak adalah sesuatu yang kita terima, sedangkan kewajiban adalah sesuatu yang harus ditunaikan atau dilaksanakan.

Sedangkan kewajiban adalah suatu yang harus dilaksanakan, keharusan (sesuatu hal yang harus dilaksanakan). ${ }^{27}$ Dalam hal ini, pemilik dan penggarap sawah harus melaksanakan kewajibannya pada perjanjian yang telah disepakati oleh kedua belah pihak. Hak dan kewajiban pemilik sawah dan petani penggarap harus ditetapkan sebelum tanah diolah oleh penggarap. Dengan demikian pemilik tanah berhak memperoleh sebagian dari hasil penggarapan sawahya pada saat dilakukannya panen yang sesuai dengan perjanjian yang telah disepakati secara bersama, dan kewajiban itu telah ditegaskan dalam Undang-Undang No.2 Tahun 1960. Undang-Undang tersebut menimbang bahwa perlu diadakan Undang-undang yang mengatur perjanjian pengusahaan tanah dengan bagi hasil, agar pembagian hasil tanahnya antara pemilik

${ }^{25}$ Hukum.unsrat.ac.id, "Undang-Undang Republik Indonesia Nomor 2 Tahun 1960 Tentang Perjanjian Bagi Hasil," last modified 2020, http://hukum.unsrat.ac.id/uu/uu_2_1960.htm.

${ }^{26}$ Islam Cendekia, "Pengertian Hak Dalam Islam," last modified 2014, accessed January 8, 2020, https://www.islamcendekia.com/2014/03/pengertian-hak-dalam-isla.html.

27 Serafica Gischa, "Arti Kewajiban Dan Jenis-Jenisnya," Kompas.Com, last modified 2020, https://www.kompas.com/skola/read/2020/01/03/140000269/arti-kewajiban-dan-jenis-jenisnya. 
dan penggarap dilakukan atas dasar yang adil dan agar terjamin pula kedudukan hukum yang layak bagi para penggarap itu, dengan menegaskan hak-hak dan kewajiban-kewajiban baik dari penggarapan maupun pemilik.

Berdasarkan uraian di atas dapat ditarik kesimpulkan bahwa hak dan kewajiban pemilik tanah atau sawah dan penggarap yang telah di tetapkan di Desa Bedegung Kecamatan Semidang Aji sesuai dengan hukum Islam, semua diterapkan demi untuk menjaga agar penggarap dan pemilik tanah tidak mengambil bagian atau harta sesamanya dengan jalan bathil sebagaimana firman Allah swt dalam surah Al-Baqarah ayat 188 sebagai berikut:

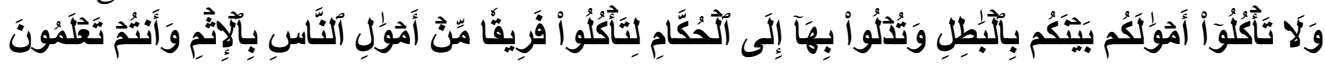

Artinya: "Dan janganlah sebahagian kamu memakan harta sebahagian yang lain di antara kamu dengan jalan yang bathil dan (janganlah) kamu membawa (urusan) harta itu kepada hakim, supaya kamu dapat memakan sebahagian daripada harta benda orang lain itu dengan (jalan berbuat) dosa, Padahal kamu mengetahui”.( QS. Al-Baqarah ayat 188)

\section{Analisis Sistem Bagi Hasil Penggarapan Sawah di Desa Bedegung Kecamatan} Semidang Aji

Berdasarkan hasil yang didapatkan dilapangan pada wawancara 10 pemilik sawah dan 10 penggarap di Desa Bedegung adalah berikut. Kerjasama dalam hal bagi hasil yang masyarakat lakukan tidak ada akad yang mengikatnya (akad tertulis), tetapi seakan-akan telah terjadi kesepakatan (akad). Bentuk akad kebanyakan yang terjadi dilakukan secara lisan atas dasar suka sama suka, rela sama rela, ikhlas sama ikhlas dan saling percaya tidak terlalu formal. ${ }^{28}$ Dengan cara pemilik sawah mendatangi penggarap dan menyuruhnya untuk mengerjakan pekerjaan, menggunakan akad lisan tanpa menggunakan perjanjian tertulis, atau pun petani penggarap yang mendatangi pemilik sawah untuk menggarap sawah miliknya.

Sebagai imbalan atau upah, si penggarap berhak atas nisbah tertentu dari hasil panen. Pemberian imbalan atau upah bagi penggarap harus mencerminkan keadilan, dan mempertimbangkan berbagai aspek kehidupan, sehingga hak penggarap dalam menerima imbalan atau upah lebih terwujud. Imbalan atau upah yang diberikan kepada seseorang harus sebanding dengan kegiatan yang telah dikeluarkan. Pemberian imbalan atau upah hendaknya berdasarkan akad (kontrak) perjanjian kerja. Karena akan menimbulkan hubungan yang berisi hak- hak atas kewajiban masing-masing pihak.

Akad yang terjadi di Desa Bedegung adalah akad Muzara'ah dan Mukhabara. Muzara'ah dan Mukhabara pada dasarnya sudah menjadi kebiasaan sebagian masyarakat dalam pemenuhan kebutuhan hidup sehari-hari di Desa Bedegung Kecamatan Semidang Aji. Peneliti juga merasa adanya kesenjangan antara teori dan praktik yang terjadi, bahwa praktek muzara'ah dan mukhabara yang dilakukan oleh pemilik sawah terhadap pengelola (penggarap) di Desa Desa Bedegung Kecamatan Semidang Aji tanpa akad yang jelas. Sedangkan dalam al-Qur'an surat al-Baqarah ayat 282 berbunyi :

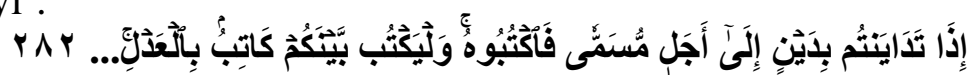

Artinya : "apabila kamu bermuamalah secara tunai dan waktu yang ditentukan hendaklah kamu menuliskannya dan hendaklah seorang penulis diantara kamu menuliskannya dengan benar. (Qs. Al-Baqarah : 282)

Islam menganjurkan akad kerjasama harus dilakukan secara tertulis dan tidak dilakukan secara lisan agar terhindar dari hal-hal yang bisa merugikan dalam suatu kerjasama. Dilihat dari segi jangka waktu kerjasama masyarakat Desa Bedegung ini

${ }^{28}$ Wawancara dengan Mahyudin, Masyarakat, Bedegung, 02 Januari 2020, Jam 10:06 WIB 
tidak ditentukan untuk berapa kali panennya, dikhawatirkan kedepannya dapat menimbulkan permasalahan yang akan timbul dikemudian hari, sama halnya dalam penjelasan al-Qur'an surat Al-Baqarah ayat 282, jika bekerjasama dalam usaha atau sejenisnya harus memiliki jangka waktu yang ditentukan, maksudnya adalah dalam suatu perjanjian harus ada batas waktu atau kejelasan waktu berapa lama perjanjian kerjasama tersebut. Namun ada sebagian masyarakat yang menentukan jangka waktu kerjasamanya antara pemilik sawah dan petani penggarap secara lisan tidak dalam bentuk tertulis.

Pembagian hasil yang dilakukan masyarakat Desa Bedegung dibagi menurut kebiasaan masyarakat setempat yakni apabila semua biaya ditanggung oleh pemilik sawah, maka bagian pemilik sawah mendapat dua (2) bagian sementara penggarap mendapat satu (1) bagian. Jika penggarap menanggung biaya maka bagiannya mendapat 2 bagian sementara pemilik sawah mendapat 1 bagian. Demikian juga apabila biaya ditanggung bersama maka bagian yang didapat antara pemilik sawah dan penggarap masing-masing adalah setengah $\left({ }^{1} / 2\right) .{ }^{29}$ Sedangkan menurut Widam dan Rizal Dinata sistem bagi hasil yang mereka lakukan adalah bagai dua, setelah di kurangi biaya bibit, obatan, dan perawatan sawah, itu mereka lakukan karena petani penggarap tidak memiliki lahan untuk di garap dan untuk tolong menolong. ${ }^{30}$ Disamping itu saat pembagian hasil panen, petani penggarap tidak menghadirkan pemilik lahan atau sawah. Pemilik lahan hanya menerima pemberian petani penggarap setelah selesai pembagian.

Akad yang terjadi di Desa Bedegung adalah akad kebiasaan yang sudah berlangsung lama, akad ini harusnya diperbaiki dengan cara musyawarah dan menulis hasil musyawarah atau perjanjian tersebut demi kebaikan kedua belah pihak dengan tidak ada yang merasa dirugikan. Serta waktu pembagian hasil panen harus menghadirkan pemilik lahan dan petani penggarap. Realitas keadaan masyarakat di Desa Bedegung masih kurangnya pengetahuan, kurang mengerti akan adanya akad kesepakatan kerjasama menurut hukum Islam. Ada keharusan bagi pemilik sawah yang memperkerjakan seseorang untuk menggarap sawahnya untuk memperhatikan hak-hak dan kewajibannya. terlebih masyarakat Desa Bedegung adalah 100\% beragama Islam, tentunya harus paham dan mengerti bagaimana aturan syar'i mengenai sistem dalam bagi hasil.

Kewajiban seorang pekerja yang seharusnya adalah menyelesaikan pekerjaannya sesuai perjanjian, dan setelah perjanjian itu selesai maka pekerja berhak mendapatkan pembagian hasil yang jelas, sesuai dengan akad yang telah disepakati bersama. Begitu pula dengan petani yang memperkerjakan harus memperhatikan hak-hak petani penggarap sawah. Dengan adanya aturan demikian maka tidak ada pihak yang dirugikan, baik dari pihak pekerja maupun dari pihak pemilik sawah. Dalam Islam apabila ada salah satu pihak yang dirugikan maka akadnya menjadi tidak sah.

\section{Tinjauan Hukum Islam Terhadap Sistem Bagi Hasil Penggarapan Sawah di Desa Bedegung}

Dalam kehidupan bermasyarakat salah satu bentuk yang selalu terjadi adalah kerjasama. Kerjasama pada unsurnya adalah tolong menolong. Sebab ada orang yang memiliki tanah namun tidak memiliki keahlian untuk mengurus, ada yang dikarenakan tidak ada waktu untuk mengurusinya, ada juga orang yang tidak memiliki modal tetapi mempunyai keahlian, hal inilah yang biasanya menjadi sebab terjadinya kerjasama di Desa Bedegung agar keduanya mendapatkan keuntungan. Kerjasama bagi hasil

\footnotetext{
${ }^{29}$ Wawancara dengan M. Yanoh, Kepala Desa Bedegung, Bedegung, 02 Mei 2019

${ }^{30}$ Wawancara dengan Widam, Masyarakat, Bedegung, 02 Januari 2020, Jam 11:30 WIB
} 
merupakan kerjasama yang dilakukan antara dua orang atau lebih dalam melakukan pekerjaan dimana hasilnya akan dibagi berdasarkan kesepakatan yang telah ditentukan bersama, yang memiliki nilai keadilan diantara keduanya. Karena keadilan yang seharusnya menjadi dasar utama dalam hubungan timbal balik saat melakukan kerjasama.

Berdasarkan masalah yang ditemukan di lapangan yang telah dijelaskan pada bab sebelumnya dasar hukum musaqoh, muzara'ah dan mukhabara dalam Al-Qur'an dan As- Sunnah, dapat dipaparkan bahwa sistem kerjasama yang dilakukan masyarakat Desa Bedegung belum begitu sesuai dengan tuntunan Hukum Islam karena akad perjanjiannya masih secara lisan tidak tertulis dan tidak adanya saksi dalam perjanjian akad tersebut serta waktu pembagian hasil panen petani penggarap tidak menghadirkan pemilik lahan. dapat ditarik kesimpulan bahwa sistem bagi hasil di Desa Bedegung belum sesuai dengan hukum islam karena belum terpenuhinya syarat dan rukun muzara'ah dan mukhabara. Akad tidak tertulis dan tidak ada saksi dalam akad tersebut.

Menurut jumhur ulama, syarat pada muzara'ah berkaitan dengan orang-orang yang berakad, benih yang ditanam, lahan yang akan dikerjakan, hasil yang akan dipanen, dan jangka waktu berlakunya akad. Namun dalam prakteknya jangka waktu dalam kerjasama tidak ditentukan. Syariat Islam menganjurkan apabila bermu'amalah tidak secara tunai untuk waktu yang tidak ditentukan hendaklah ditulis, hal ini dianjurkan karena Islam benar-benar menjaga perilaku dan hubungan sesama manusia agar tetap bersilaturahmi dengan baik. Allah terang- terangan menyampaikan kepada umatnya dalam melakukan kerjasama harus menggunakan akad perjajian tertulis, sebagai mana firmanNya dalam Q.S Al-Baqarah ayat 282 :

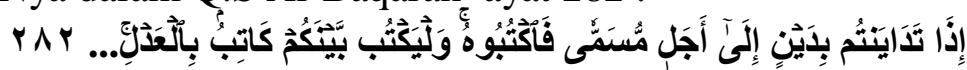

Artinya : "apabila kamu bermuamalah secara tunai dan waktu yang ditentukan hendaklah kamu menuliskannya dan hendaklah seorang penulis diantara kamu menuliskannya dengan benar. (Qs. Al-Baqarah : 282)

Pada akad, apabila salah satu saja dari rukun dan syarat terbentuknya akad tersebut tidak terpenuhi, maka akad tersebut disebut akad batil yang tidak ada wujudnya. Apabila pokoknya tidak sah, maka tidak sah pula sifatnya.

Praktek yang terjadi di Desa Bedegung ini belum sepenuhnya sesuai dengan aturan-aturan yang telah ditetapkan dalam syariat Islam. Artinya pada saat sebelum penggarap memulai pekerjaannya tidak ada perjanjian yang mengikat atau terdapat saksi yang melihat. Artinya sistem bagi hasil yang dilakukan antara penggarap dan pemilik tanah tidak sesuai dengan firman Allah SWT dalam Q.S Al-Baqarah ayat 282. Namun akad muzara'ah dan mukhabara yang dilakukan masyarakat Desa Bedegung selama ini dilakukan atas dasar suka sama suka sesuai dengan Firman Allah SWT di dalam Surah An-Nisa' ayat 29 yang berbunyi :

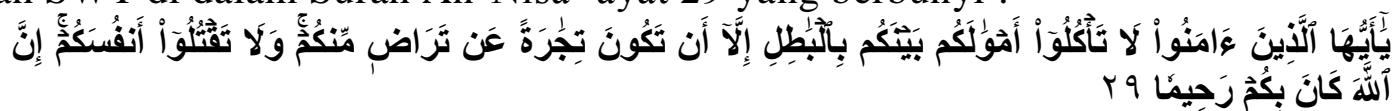

Artinya : "Hai orang-orang yang beriman, janganlah kamu saling memakan harta sesamamu dengan jalan yang batil, kecuali dengan jalan perniagaan yang Berlaku dengan suka sama-suka di antara kamu”. (QS. An-Nisaa' ayat 29)

Berdasarkan analisis diatas dapat disimpulkan bahwa sistem bagi hasil yang terjadi di Desa Bedegung tersebut belum dibenarkan oleh Hukum Islam yang 
berkaitan dengan pembahasan, ditemukan beberapa kesalahan yaitu: Masyarakat Desa Bedegung melakukan akad muzara'ah atau mukhabarah tidak adanya saksi dalam akad, akad muzara'ah dan mukhabarah hanya dilakukan atas dasar suka sama suka yang diucapkan secara lisan tanpa adanya perjanjian tertulis, jika akad perjanjian tersebut tidak ditulis maka akad tersebut terasa kurang jelas atau mengandung unsur gharar. Akan tetapi akad muzara'ah dan mukhabarah yang dilakukan masyarakat Desa Bedegung tidak sepenuhnya bertentangan dengan hukum islam karena masih berpedoman pada Al-Qur'an surah An-Nisaa' ayat 29 dan surah Al-Maidah ayat 2, karena pada prakteknya terdapat unsur tolong-menolong dan suka sama suka diantara keduanya dan tidak ada pihak yang dirugikan. Oleh sebab itu adat atau kebiasaan yang dilakukan oleh masyarakat Desa Bedegung ini dalam masalah paruan sawah atau ladang tidak bisa dihapuskan. Karena sudah dilakukan secara turun temurun dan saling tolong menolong serta tidak ada pihak yang merasa dirugikan.

\section{Simpulan}

Sistem bagi hasil di Desa Bedegung Kecamatan Semidang Aji Kabupaten Ogan Komering Ulu dikenal dengan istilah paruan. Seorang pemilik tanah menyerahkan lahan tersebut kepada penggarap untuk diolahnya dengan ketentuan apabila semua biaya ditanggung oleh pemilik tanah, maka bagian pemilik tanah mendapat dua bagian, sementara penggarap mendapat satu bagian. Jika penggarap menanggung biaya maka bagiannya mendapat dua bagian sementara pemilik tanah mendapat 1 bagian. Demikian juga apabila biaya ditanggung bersama maka bagian yang didapat antara pemilik tanah dan penggarap masing-masing $(1 / 2)$.

Tinjauan Hukum Islam tentang Sistem Bagi Hasil Penggarapan Sawah di Desa Bedegung Kecamatan Semidang Aji Kabupaten Ogan Komering Ulu adalah praktek bagi hasil yang belum sesuai dengan konsep Islam, karena mengandung unsur gharar. Ketidakjelasan yang dimaksud adalah akad muzara'ah dan mukhabarah mengenai perjanjian akad, karena pemilik tanah dan penggarap tidak menghadirkan saksi dalam perjanjian serta hasil perjanjian hanya secara lisan dan tidak tertulis. Namum tidak sepenuhnya bertentangan dengan hukum islam karena praktek yang dilakukan oleh masyarakat Desa Bedegung ini dilakukan atas dasar suka sama suka dan mengandung unsur tolong menolong sesuai dengan Surah An-Nisa' ayat 29 dan Surah Al-Maidah ayat 2. Akad muzara'ah dan mukhabarah yang dilakukan di Desa Bedegung sudah dilakukan secara turun temurun dan sulit untuk dirubah atau dihapuskan.

\section{Daftar Pustaka}

Abdul Rahman Ghazaly dan Sapiudin Shidiq. Fiqh Muamalat. Jakarta: Kencana, 2015.

Al-Asqalani, Ibnu Hajar. Bulughul Marom. Diterjemah. Jakarta: Pustaka Amani, 2000.

Antonio, Muhammad Syafi'i. Bank Syariah Dari Teori Ke Praktek. Jakarta: Gema Insani, 2001.

Cendekia, Islam. "Pengertian Hak Dalam Islam." Last modified 2014. Accessed January 8, 2020. https://www.islamcendekia.com/2014/03/pengertian-hak-dalam-isla.html.

Hendi Suhendi. Fiqih Muamalah. Jakarta: PT. Raja Grofindo Persada, 2013.

Hukum.unsrat.ac.id. "Undang-Undang Republik Indonesia Nomor 2 Tahun 1960 Tentang 
Perjanjian Bagi Hasil.” Last modified 2020. http://hukum.unsrat.ac.id/uu/uu_2_1960.htm.

M. Subana, Sudrajat. Dasar-Dasar Penelitian Ilmiah. Jakarta: CV Pustaka Setia, 2011.

Malik, Mochammad Kamil, Sri Wahyuni, and Joko Widodo. "Sistem Bagi Hasil Petani Penyakap Di Desa Krai Kecamatan Yosowilangun Kabupaten Lumajang." JURNAL PENDIDIKAN EKONOMI: Jurnal Ilmiah Ilmu Pendidikan, Ilmu Ekonomi dan Ilmu Sosial 12, no. 1 (2018): 26.

Mardani. Fiqh Ekonomi Syariah. 1st ed. Jakarta: Kencana, 2012.

Muslich, Ahmad Wardi. Fiqh Muamalah. Jakarta: Sinar Grafika, 2006.

Rachmat Syafe'I. Fiqh Muamalah. Bandung: Pustaka Setia, 2000.

Ruslan, Rosady. Metode Penelitian: Public Relations \& Komunikasi. Jakarta: Raja Grafindo Persada, 2008.

Serafica Gischa. “Arti Kewajiban Dan Jenis-Jenisnya.” Kompas.Com. Last modified 2020. https://www.kompas.com/skola/read/2020/01/03/140000269/arti-kewajiban-dan-jenisjenisnya.

Sohari Sahrani, Ruf'ah Abdulla. Fikih Muamalah. Bogor: Ghalia Indonesia, 2011.

Unggul Priyadi dan, and Jannahar Saddam Ash Shidiqie. "Pelaksanaan Perjanjian Bagi Hasil Pertanian Lahan Sawah Studi Di Studi Di Kecamatan Gamping, Kabupaten Sleman Yogyakarta." Millah XV No 1 (2015): 101-115. www.regionalinvestment.bkpm.go.id.

Wahyuningsih, Tri. "Sistem Bagi Hasil Maro Sebagai Upaya Mewujudkan Solidaritas Masyarakat." Komunitas: International Journal of Indonesian Society and Culture 3, no. 2 (2013): 197-204. 